University of Warwick institutional repository: http://go.warwick.ac.uk/wrap This paper is made available online in accordance with publisher policies. Please scroll down to view the document itself. Please refer to the repository record for this item and our policy information available from the repository home page for further information.

To see the final version of this paper please visit the publisher's website. Access to the published version may require a subscription.

Author(s): Ben Clift

Article Title: Debating the Restructuring of French Capitalism and AngloSaxon Institutional Investors: Trojan Horses or Sleeping Partners?

Year of publication: 2004

Link to published version:

http://dx.doi.org/10.1057/palgrave.fp.8200062

Publisher statement: This is a post-peer-review, pre-copyedit version of an article published in French Politics. The definitive publisherauthenticated version [Clift, B. (2004). Debating the Restructuring of French Capitalism and Anglo-Saxon Institutional Investors: Trojan Horses or Sleeping Partners? French Politics, 2, pp. 333-346] is available online at: http://dx.doi.org/10.1057/palgrave.fp.8200062. 
Ben Clift, University of Warwick

'Debating the Restructuring of French Capitalism and Anglo-Saxon Institutional Investors: Trojan Horses of Sleeping Partners?' (Review Article) French Politics Volume 2, Number 3 (2004), pp. 333-346. ISSN 1476-3419.

For some time now, scholars of French capitalism have been noting how, in its most recent articulation, the state is apparently disengaging from the market, abstaining from intervention and encouraging competition, yet decision makers in the main industries and government still form a close circle and continue to collaborate. A number of recent studies of French capitalism have unearthed how these features remain pertinent today, but the evolution of the French model has taken it further down the line to a more marketoriented capitalism, with still less direct state intervention (Morin 2000; Goyer 2001; Culpepper 2004; Schmidt 2002 \& 2003).

Two distinct phases in the restructuring of French capitalism in the last two decades can be discerned. Firstly, a phase of 'protected' restructuring behind barriers between roughly 1983 and 1996, when the state’s preponderant role, and through mechanisms such as the noyaux durs, which articulated the core of France 'financial network economy' (Morin 2000; Schmidt 1996) was able to direct the adjustment process to a considerable degree. From 1996 onwards, however, there has been a progressive dismantling of elements of the protective cocoon behind which elites restructured the French economy.

Sufficient time has elapsed since the onset of this new phase of restructuring to begin to draw (partial, interim) conclusions about the nature of French capitalism in their wake. This review article considers a range of scholarship engaged in that task. What is happening to the French of capitalism? In the wake of two decades of dramatic evolutions, are we faced with a new model, (and, if so, in whose image has it been forged?), or is it the old model, suitably patched up?

From the 'Varieties of capitalism' perspective, which distinguishes between two basic models of capitalism - liberal market economies (LME) (co-ordinating activity primarily 
through hierarchies, competitive markets and contracts) and co-ordinated market economies (CME) (dependent more on non-market relations, with networks and collaborative arrangements for exchanging information playing a key role) (Hall \& Soskice 2001), the French model represents something of a problem case. The 'varieties of capitalism' approach tends towards the dichotomous framing which appears congenital to comparative political economy debates. Yet this is not always particularly helpful in relation to a French case which eludes easy categorisation and appears to span the divide in a number of important respects (Culpepper 2004: 2; Schmidt 2002; 2003).

Jonah Levy argues that the French welfare state 'is a social scientist's worst nightmare' (Levy, 2000: 315) because of its Byzantine complexity, and its peculiar path dependent development making it difficult to reconcile to comparative welfare models with which it does not really fit. This insight could be applied to the French model of capitalism generally. This may ultimately be no truer of France than of any other model of capitalism, but French politics scholars tend to have a presumption of the exceptionalism of their case (see e.g. Chafer \& Godin, 2004). To paraphrase George Orwell, all models of capitalism are unique - but some, French scholars claim, are more unique than others.

Schmidt's solution to this problem is to posit a third, statist, type of capitalism, and present the French model as the archetype (2002; 2003). Yet is French capitalism distinctive enough to posit another category? Furthermore, as the complex processes of hybridisation which most models of capitalism scholars see unfolding and impacting upon national models (Perraton \& Clift, 2004) progress, will the case for a third European variety of capitalism become more difficult to sustain?

A couple of methodological reflections should precede our etat des lieux of the contemporary debate. Firstly, 'models' of capitalism are an ensemble, embedded in a social and institutional context, and 'institutionally interlocked' (Soskice, 1997, 220). There is a need to conceptualise our model of capitalism as an institutional ensemble in order to capture French capitalism in its complexity. Secondly, it is important to engage with transformation, and potential causes thereof, at a number of levels of analysis, 
specifically, the national, the European, and the global, and to attempt at least to discern the relative importance of endogenous and exogenous pressures and forces for change (see e.g. Clift 2003b).

Hancké's in-depth exploration of large firms, for example, is valuable because it 'drills down' to offer 'thick description' of changes within key institutions such as Renault and EDF. However, it is not unproblematic. The key difficulty is the flip-side of its main strength, and relates to the 'levels of analysis' issue. Taking the firm as a level of analysis is perfectly justified, but concentrating on that level top the exclusion of other levels is clearly problematic. The approach or focus of models of capitalism analysis shapes the narrative that emerges, and it is remarkable what can be omitted. In Hancké's booklength study of restructuring the French economy, with particular focus on EDF, there is simply no mention of the EU, Single Market, competition policy, anti-trust legislation, or energy and telecoms market liberalisation. Given the significance of all the above for the transformation of the French model (see e.g. Clift 2003b), this is difficult to justify. Hancké's account clearly underplays exogenous pressures, which doubtless play at least as significant a role.

Thus the focus of models of capitalism analysis shapes the emergent narrative. Hall and Soskice's important study asserts the primacy of an approach which analysis the evolutions and dynamics of capitalism from the standpoint of the company. Schmidt notes how the focus of analysis importantly shapes the degree of retreat of the state posited. A focus on financial markets (Morin 2000), or on firms (Hancké 2002), Schmidt argues, underplays the role of the state, and neglects the enduring 'state-enhanced' nature of French capitalism (2003: 527; 2002). Yet the problem may not be absent from Schmidt's own work, which focuses on state policies, and as a result may overplay the 'statist' nature of the contemporary French model. This is a particularly significance issue with relation to her work, since it is on the role of that state that her claim that the French model represents a distinctive variety of capitalism hinges. 
The complexity of French capitalism may tell against attempting to construct a single narrative across all sectors and institutional areas of the French model. As Gamble notes, 'Critics of models of capitalism argue that these models presuppose a unity that does not exist ... Each national economy in any case is normally a hybrid, with different models in different sectors, rather than a single model throughout.' $(2004,4)$ We need to consider the possibility of different stories emerging in different sectors, for example. Those asserting the third (state-enhanced) variety argument need to establish the relative importance of the statist model elements - and whether they achieve a critical mass sufficient to justify a variety of capitalism all of their own.

\section{Debating the French Model}

Here we will confine ourselves to the two dominant positions in the debate. Firstly, there is a convergence on LME-type economy thesis, advanced with varying degrees of precision and care (Morin 2000; Goyer 2001; Culpepper 2004). Culpepper, for example, presents a case for profound transformation of the French model towards a 'post-statist' capitalism as a result of the state losing control in 1980s and 1990s, heralding a sharp rise in uncoordinated action (lurking in the shadows here is the 'LME' ideal-type) (2004). Although Culpepper is at pains to critique the 'Varieties of capitalism' account, pointing out that it does violence to the subtlety and nuance of the true picture of French capitalism, he ends up on the verge of forcing his characterisation of the French model into the LME pigeonhole (2004).

Culpepper's notion 'state-controlled' capitalism (2004) is a rather misleading representation of the relationship between state and business in the 'glory years'. Indeed, it is not a helpful way of thinking about it state/market inter-relationships in France, either in the contemporary period, or going back through the twentieth Century. An extensive literature questions the coherence of the picture advanced by Zysman (1983), and a debate remains as to how much 'glorious' growth was really due to indicative economic planning and strategic interventionism in industry creating 'national champions' (see for example Hancké 2001: 309-12; Guyomarch et al 1998: 161-68). 
Hayward and others pointed to business successes at exploiting and manipulating the interventionist state (1986; see also Schmidt 2003: 529). Loriaux highlights how 'industrial policy was frequently 'captured' by the economic sectors it was designed to serve and develop, with the result that the state became a provider of sectoral rents rather than the instrument of national economic modernisation.' (2003: 105) Thus Culpepper's account misrepresents earlier state/market inter-relationships and contemporary state coordination. The French state continues to attempt to pursue a quasi-dirigiste strategy, by novel means, and with less direct intervention (Clift 2001; 2003 a \& b; 2004; MacLean 2002; Loriaux; 2003; Schmidt 2003).

More generally, this account of profound transformation lacks detail of the causal explanations of what the changing shareholding patterns, and other changes highlighted, mean for French capitalism. Furthermore, to reiterate our point about avoiding a narrow focus in assessing the evolution of French capitalism, scholars convinced of the convergence thesis tend to neglect profound and deeply embedded continuities is key organising features of French capitalism, such as company and labour law, which should lead to qualification of bolder assertions of convergence.

The other main position points more towards continuity than change, arguing that France's model remains distinctive, primarily because the state continues to play a distinctively significant role (Clift 2003b \& 2004; Schmidt 20003; Loriaux 2003). These scholars claim, France's 'flexible Fordism' (Schmidt 2003: 545), or 'flexible mass production’ (Hancké 2002) capitalism remains distinctive, and distinctly statist. Although continuity is a refrain of this account, these scholars take account of and explore the very dramatic changes and transformations that French capitalism has undergone in recent decades. These include financial market liberalisation, business deregulation and privatisation, and labour market decentralisation.

Yet convergence cannot, these scholars argue, be 'read off' from such transformations. MacLean, for example, in her analysis of corporate governance where talk of 'AngloSaxonisation' is most prevalent, notes 'a convergence with Anglo-Saxon financial 
capitalism is unlikely to be in the offing' (1999: 106). These scholars all note that the means by which the state exercises its interventionist 'enhancing' role, are changing. Analysing the French model, and the place of large firms within it, Hancké notes 'the defining features of the existing French model reasserted themselves: the large firms, the state, and the particular governance mechanisms that organized the ties between them but it a different configuration ... while the market today certainly plays a bigger part in the French economy than twenty-five years ago, France has not become a deregulated economy of the Anglo-Saxon kind' (2002: 3 \& 8).

\section{Breaking down the barriers: the move away from protected restructuring.}

Goyer notes a number of significant shifts within the 'financial networks' that hitherto articulated the core of the French economic model. The noyaux durs which had been maintained by merger and acquisition strategies that sustained cross-shareholding began to unravel in a fairly dramatic fashion in the late 1990s, precipitated notably by privatisation. The equity stake of hard-core shareholder groups fell significantly, and the equity holding of foreign investors, notably Anglo-Saxon institutional investors, grew substantially. Goyer offers evidence from the selling of subsidiaries, and of businesses where the conglomerate possesses no comparative advantage, that focus on core competencies is a key motivation behind the sell-offs of shares which have heralded the partial unravelling of the noyaux durs (2001 146-8). This suggests that the ethos of 'protected capitalism' (Schmidt 1996) was on the wane, and a Anglo-Saxon 'shareholder value' logic was gaining currency.

The shareholding links which AXA-UAP enjoyed with many key players across the various hard cores could have given AXA a pivotal role in orchestrating France's 'financial network economy', yet it chose to relinquish significant stakes in a range of major firms, and retained only those holdings it saw as essential to its core business. This began a trend since emulated my other significant players within the noyaux durs, notably with the Allianz -AGF buy-out in 1997 (Morin 1998, 2000; Goyer 2001, 2003; O’Sullivan 2003). 
Extremely healthy French profit margins since the mid-1980s created capital used aggressively by French firms in Mergers and Acquisitions (M \& A) activity, particularly in the U.S., in part in order to acquire radical innovation capacities, 'as a result of this shopping spree, the activities of the American subsidiaries are an important component of the business strategy of French firms today’ (Goyer 2001: 153). M \& A saw a very sharp increase in late 90s, with 1999 and 2000 showing particularly spectacular levels of French firm acquisition of foreign companies in particular (UNCTAD World Investment Report 2003; Kechidi 2003; tables 1 \& 2). This frenzied process, most analysts concur, was the product of both the privatisation process, and the partial unravelling of the noyaux durs (Morin 2000).

One marked feature of the restructuring process is the internationalisation of ownership and shareholding patterns in France. The recent expansion in foreign holdings on the French stock exchange is remarkable (MacLean 2002: Table 7.7). Between 1985 and 1997, foreign owners increased their share of stock exchange capitalization from 10 per cent to 35 per cent (compared to 9 per cent in Britain, and 6 per cent in the US) (Morin, 2000). By November 2000, of CAC 40 (top 40 French firms), the average foreign equity holding was over 40\% - a record among world's leading industrial nations (MacLean 2002: Table 7.7). Morin charts a 'highly significant trend' of the increasing purchase by North American pension funds and fund managers of the stakes in French firms relinquished by the noyaux durs. The scale of the holdings is such that, 'in some cases, such as Alcatel, the foreign mutual funds alone hold a greater proportion of the capital than is controlled by the group of committed shareholders.' (2000: 43)

Morin argues that this presages a sea change in French capitalism, away from the protective logic of unrelated cross-shareholdings and towards Anglo-Saxon shareholder value norms. More recent evidence from a survey commissioned by Le Monde ${ }^{1}$ indicated that the influx had reached a plateau at around 43\% foreign ownership of French stock.

\footnotetext{
${ }^{1}$ Laurent Mauduit 'Du capitalism rhénan au capitalisme americain, la mutation de l'économie s’accélere' Le Monde 29. 07. 2003.
} 
All this data should be treated with some caution, since companies are sometimes unwilling to release data regarding the identity of their shareholders, and this is at times because they cannot identify them. ${ }^{2}$ Nevertheless, this high proportion of foreign equity holdings on the Paris bourse has acquired totemic status within the French political economy debate as indicating a paradigm shift. Yet what does this fact mean? What is its causal significance for scholars of the French model of capitalism?

\section{Interpreting the Transformation of French Capitalism}

Consistent with the positions on the French model outlined earlier, interpretations vary widely. Goyer boldly asserts the degree of change; 'the transformation of the French system of corporate governance is nothing short of impressive: in less than a decade, France shifted from an insider to an outsider model.' (2001: 148) Goyer qualified this position in a later piece (2003), but the interpretation of U.S. institutional investors as the vanguard of Anglo-Saxon capitalism is widespread.

It does seem to have coincided with strategic and operational behaviour that generates value potentially transferable to shareholders. Can this correlation be treated as causation? Morin sees the 'dominant strategic model' of American institutional investors as a growing influence, demanding concentration of ownership, defence of 'core business', breaking up of conglomerates, externalising 'non-strategic' activities, constant communication between managers and major shareholders, and behaviour such as share buy backs a means of increasing shareholder value (Morin, 2000: 48-9; MacLean, 1999: 104-105). It seems to have played some role in advancing France further down road posited by Morin from financial network on to financial market economy (2000; see also Goyer 2001).

Others are keen to qualify such claims. O'Sullivan's analysis of change in both France and Germany notes that 'neither country has gone so far as to create a system of corporate governance in which the stock market is as prominent as it is in the US and

\footnotetext{
${ }^{2}$ Cécile Ducourtieux ‘La France s’ouvre de plus en plus aux fonds anglo-saxons’ Le Monde 29. 07. 2003.
} 
UK' (2003: 25; see also Schmidt 2003). The problem of interpretation of these changes is that it is difficult to establish empirically the link between this ownership of equity and any direct impact on how firms behave strategically. Kechidi insists that at most one can talk about the new ownership patterns 'influencing behaviour' of firms, not 'controlling' them (2003), and Morin's account also points to the interaction of Anglo-Saxon norms with enduring French institutions, such as the French social model (2000).

The power of UK/US institutional investors to transform 'domestic' corporate governance practises appears widely accepted (Morin 2000). Yet two qualifications are required. Firstly, the degree of change should not be overestimated, and the possibility of different degrees of change within different aspects of corporate governance must be admitted. Secondly, change should not be viewed as simply imposition on domestic corporations by global financial markets. Changes in corporate organisation along more 'Anglo-Saxon' lines have a number of domestic origins as well. Care must be taken to explore the interplay of endogenous pressures and exogenous pressures for change, and establish the relative importance of each. Hancké's detailed account of large French firm restructuring in France, for example, offers an explanation based on internal desires for change. His book scarcely mentions overseas business models or influence (2002). Whilst Hancké probably overstates the significance of these endogenous pressures for corporate governance change (see below), they should clearly should not be ignored.

\section{Towards French 'Shareholder Value’ Capitalism?}

The key concerns of the shareholder value paradigm as related to 'good' corporate governance were distilled into an agenda for 'good' corporate governace by the OECD (1999), which have acquired international currency. There have been differential degrees and speeds of take-up of the new procedures and institutions of shareholder value paradigm. This reiterates the point made above regarding domestic as well as international sources of change occasionally neglected in international political economy analyses that underplay the interaction between global and domestic forces. 
Of central importance are transparency and accountability. The policy corollaries of this are a concern for the quality of information on the management structure of firm, the degree of independence of its (in particular non-executive) board members, the adoption of Anglo-Saxon accounting norms. Also, in structural or constitutional terms, the agenda demands in relation to the rights and duties of shareholders a principle of one share, one vote, one dividend. The procedures for composition of and election to boards is subject to scrutiny, but most significant is the demand for the separation of the role Président Directeur Générale (PDG) into two discrete posts. Lastly, in terms of executive remuneration, there is a demand for 'stock-option' style incentivising, and also transparency surrounding the level and nature of executive remuneration to ensure accountability (Jeffers \& Magnier 2002: 61-3).

All studies highlight the unevenness of take-up of these different policy corollaries. Unsurprisingly, French top managers (their eyes lit up with dollar signs) have been all for stock options and U.S.-style huge executive remuneration packages, but rather less hasty to institute greater transparency, Intnerationalised accounting standards, or more stringent criteria for awarding options (Goyer 2003: 6; see also O’Sullivan 2003: 41). At an early stage in the evolution of the 'highly significant trend' of inward investment by AngloSaxon institutional investors steeped in the shareholder value paradigm, Morin saw them as active shareholders - monitoring management methods and decisions, make voices heard (1998). However, some years on, Goyer has noted the ongoing lack of monitoring of executive compensation, which presents an open door to financial scandal (2003). MacLean too notes significant resistance amongst some of France's largest firms to the push towards transparency and accountability (MacLean 2002: 210). Evidence from stock-based managerial remuneration and compensation indicates the ongoing autonomy of French PDGs from shareholders, and the relative lack of discipline. Shareholders possess extremely limited information about and over little control over them, with the board free to determine all the critical details. Furthermore, 'shareholders in French corporations are also precluded from exercising indirect control over share option awards, through protesting them, by a lack of transparency’ (O’Sullivan 2003: 58). 
The uneven distribution of new corporate governance institutions and processes also flags up their limited import and impact on French capitalism. Stock options are limited to top executives, and less than $1 \%$ of French employees eligible in 2001. This suggests that the advent of stock options in France are not part of a wider systemic change (Goyer 2003: 4). The micro-foundations of shareholder value paradigm are not, it seems, taking root. This is partly because schemes have not been opened up to most employees, but also because popular capitalism not that popular! As O'Sullivan has observed, "shareholder value" developed nothing like the domestic legitimacy in France that it acquired in the U.S.' (O’Sullivan 2003: 42; see also Hancké 2002 51-5).

It is in (arguably the most important) the area of executive, and particularly PDG autonomy, that least change has been seen. The post itself has not been split into two as Anglo-Saxon best practice recommends. Indeed, Hancké argues that managers of large firms have enhanced their autonomy in recent years (2002). This is startling given the degree of autonomy traditionally enjoyed by French managers. The French 'model' has traditionally been predicated upon a distinctive set of corporate governance arrangements, characterized by Napoleonic boardroom power relations. Boards are characterized by the exorbitant powers resting with their PDG, 'in French law, executive authority vests in the PDG and he has the sole right to "represent" the company, a power which only he can delegate' (Charkham, 1995: 131). Boards tend to be rubber stamps for the largely autonomous PDG. In a system characterized as 'capital without sanction' company bosses are highly autonomous.

One share, one vote is by no means universal, with a whole range of variations (quotas, non-voting shares, multiple voting hares, share ceilings) design to place control of the firm's key decisions within 'safe' hands (Goyer 2001, 2003). The concentration of ownership in France remains considerably higher than in Anglo-Saxon economies. More than half of the top 250 French firms are predominantly family owned. ${ }^{3}$ Hancké notes, 'many of the mechanisms and outcomes that are conventionally associated with a marketled adjustment process are remarkably absent from the French economy today' (2002:

\footnotetext{
${ }^{3}$ Stephane Lauer 'Malgré la mondialisation, le capitalisme familial se porte bien’ Le Monde 30.07.02.
} 
26). Calls for reform of French corporate governance, such as the Vienot reports, recommended the introduction of 'administrateurs indépendents' (external, independent, board members). These calls have largely been answered, but not in such a way as to challenge PDG autonomy. It is often the PDG who chooses these individuals, on the basis of friendship networks. As one insider observed, 'they may be independent of the shareholders, but not of the PDG' ${ }^{4}$

The traditional French problems of over powerful and under supervised PDGs, are exacerbated by French board members 'overwhelmingly compliant to the wishes of the PDG' (MacLean 1999: 104). The degree of 'incestuousness' and 'cosy complacency' (MacLean 1999: 104) which hitherto insulated French senior managers and protected their autonomy has probably been reduced by the partial unravelling of the noyaux durs noted above. Yet the evolution of the managerial and financial structure of French capitalism should not be exaggerated. Indeed, it is not at all clear that the fundamental power relations institutionalised in the constitutional structure of French firms has changed much - if at all. Studies continue to point to the exceptional PDG autonomy in France, which has been retained as French capitalism is restructured (Schmidt 2003: 53940; Loriaux 2003: 113-4 \& 117-8; Hancké 2002: 62-5). The PDG still enjoys Napoleonic powers. The suspicion remains that the changing board composition, for example, could be overstated as a source of change within French capitalism. This is likely to be the case when the autonomy of PDGs vis-à-vis the board is underestimated.

From this analysis of the internal corporate governance arrangements within large French firms, and the dynamics of their change, we could argue that the key desiderata in the evolution of French corporate governance are the levels of autonomy and rapacity of French PDGs. We could further argue that these have not changed substantially in recent years despite the dramatic restructuring of French capitalism taking place around them, and in no small part orchestrated by them.

\footnotetext{
${ }^{4}$ Martine Orange 'Ce petit cercle d'administrateurs qui se partage les responsabilités en France' Le Monde 19. 07. 2002.
} 


\section{No Longer 'capitalism without capital' ...}

All scholars point to dramatic changes in evidence, and most focus first and foremost on 'headline' rates of change in levels of stock market capitalisation, and volume of share trading. Both have seen dramatic increases in the 1980s and 1990s compared to the 1970s (O’Sullivan 2003: 39; Goyer 2003: 5; Schmidt 2003: 537-8). As Goyer notes, 'the stock market capitalization of French companies has sky-rocketed in recent years, leaving the other continental European economies well behind in terms of capitalization as a proportion of GDP’ (Goyer 2003: 4).

These trends and levels of stock market capitalisation and activity in France clearly indicate a significant shift, which could be interpreted, along the lines of the dichotomous oppositions of which the 'varieties of capitalism' literature appears so fond, of a shift from a state led to a market led, or from a bank based to an asset based form of capitalism (see e.g. Culpepper 2004). Morin points to the 'new way in which the French stock exchange operates’ as evidence of ‘ managerial revolution’ which he deems to be ‘directly inspired by the American 'shareholder value’ model’ (2000: 37). Morin argues 'the French economy is beginning to operate in the same way as the American and British economies' (2000: 37; 1998). However, such a case would have to be founded on

a careful setting out of the causal mechanisms by which these changes in French financial capitalism have changed behaviours norms and institutions within French capitalism more widely.

Capital markets play a very different role in the new French model of capitalism that that prescribed by the advocates of Anglo-Saxon model in terms of its dynamism in driving innovation, new ventures, and as a source of internal investment. A key mechanism of influence of Anglo-Saxon corporate governance is dispersal of ownership, yet the distribution of share ownership has not changed in France in recent years. France has yet to develop a market for corporate control, and real power not shifted to shareholders, and shareholding remains much more concentrated in France than is the case in either UK or US (O’Sullivan 2003: 42; see also Schmidt 2003: 539). 


\section{Conclusions}

Assertions of fundamental, 'Anglo-Saxon' transformation should, it seems, be treated with caution. Pre-existing norms and structures endure, and interact with new influences. There is a tendency to overemphasise evolutions (notably deregulation and liberalisation) at the international level, and to underplay continuities (such as corporate law and governance structures, labour relations norms) at the national level. What is sometimes lacking is an in-depth exploration of the causal mechanisms by which change is brought about within the French model. The close-knit and previously relatively impervious networks are being partially opened up by the influx of both foreign investors, and foreign investment and corporate governance norms. Yet the evolution in French corporate governance arrangements is not a teleological process of convergence towards the Anglo-Saxon model of capitalism.

The suspicion remains that, once we 'drill down' and explore the interaction of external Anglo-Saxon influence (such as U.S. Pension funds) and domestic norms, institutions, and practices, the degree of Anglo-Saxon evolution is considerably less than first impressions might suggest. The example of French corporate governance and large firm interactions considered above suggests France still straddles the comparative political economy divide. On the one hand, ‘Anglo-Saxon' influences have been introduced through American institutional investors, on the other, the French Président -Directeur Générale (PDG) - a position whose very existence points to the limited impact of US 'shareholder value'-oriented corporate governance norms, since this paradigm would see those role separated out into two discrete posts - still enjoys an exceptional degree of autonomy, and the same grand corps elitist networks continue to populate French boardrooms, and shape the evolution of French capitalism.

Schmidt's posited third, statist, type of capitalism is at first sight appealing, given the paucity of fit between the French model and the dichotomous LME/CME varieties of capitalism distinction. However, for this characterisation to remain pertinent and valid in 
the contemporary period, it must establish by what mechanisms and means state influence can endure in the changing context to more internationalised capital markets. Gone is the powerful leverage of the French state's gatekeeper role in relation to industrial financing. The French model has undergone dramatic change in the last two decades, partly as a result of policy choices made by successive French governments, and indeed as a result of the unintended consequences of these choices.

Thus we need to establish the relative importance of the statist model elements - and whether they achieve a critical mass sufficient to justify a variety of capitalism all of their own. All agree that state role is changing profoundly, and direct influence is being eroded. The role of elite networks, and the state, continued in the orchestration of noyaux durs that, despite evolution, predominated until the late 1990s. Yet the barriers behind which French capitalism have been progressively dismantled in the last decade. As a result, the case for a third European type of capitalism may become more difficult to sustain.

Further research needs to chart the impacts of the widely noted changes in the ownership structure of French firms, and trace the causal mechanisms by which change is brought to bear on French capitalism, affording due weight to the different (national, regional, global) levels of analysis. Only then can firmer conclusions ne drawn about the character of the complex institutional ensemble that is the French model of capitalism.

\section{Bibliography}

Chafer, T. \& Godin, E. 2004 The Elusive French Exception Oxford: Berghahn Charkham, J. (1995) Keeping Good Company Oxford: Oxford University Press. Clift, B. 2004 'The French Model of Capitalism: Still Exceptional?' in Perraton \& Clift (eds.) Where Are National Capitalisms Now? (Palgrave 2004), pp 91-110. Clift, B. 2003a. French Socialism in a Global Era. London: Continuum. Clift, B. 2003b. 'The Changing Political Economy of France: Dirigisme under Duress'. In M. Ryner, A. Cafruny, eds. A Ruined Fortress? Neo-Liberal Hegemony and Transformation Europe, pp. 173-200 New York: Rowman \& Littlefield. Culpepper, P. 2004. 'Capitalism, Coordination, and Economic Change: the French Political Economy since 1985’ viewed at 
http://ksghome.harvard.edu/ .pculpepper.academic.ksg/changes\%20in\%20French\%20po litical\%20economy,\%20v2.pdf

Gamble, A. 2004. 'A British Miracle? The UK Model of Capitalism', Paper presented at the PSA Conference, University of Lincoln, April 2004.

Goyer, M. 2001. 'Corporate Governance and the innovation system in France: 19852000’ Industry and Innovation. 8:2 : 135-158.

Goyer, M. 2003. 'The Transformation of Corporate Governance in France' Brookings Institution, US-France analysis Series.

Guyomarch, A., Machin, H., Ritchie, E. 1998. France in the European Union.

Basingstoke: Macmillan.

Hancké. B. 2002 Large Firms and Institutional Change Oxford University Press.

Hancké. B. 2001. 'Revisiting the French Model: Coordination and Restructuring in French Industry'. In D. Soskice, P. Hall, eds. Varieties of Capitalism, pp. 307-336 Hayward, J. 1986. The State and the Market Economy Brighton: Harvester Jeffers, E. \& Magnier, V. 2002 'Le gouvernement des enterprises et les FIE au niveau international' in Plihon \& Ponssard (eds.) La montée en puissance des fonds d'investissement (Paris: La documentation Française), pp. 55-66.

Kechidi, M. 2003. 'Fusions et Acquisitions: la financiarisation des logiques de concentration’ Working Paper, LEREPS, Université de Toulouse.

Levy, J. 2000. 'France: Directing Adjustment?' in F. Scharpf \& V. Schmidt, Welfare and Work in the Open Economy: Volume 2, pp. 337-344. Oxford: Oxford University Press. Loriaux, M. 2003, 'France: a new 'capitalism of voice'?' in Weiss (ed.) States in the Global Economy C.U.P.

MacLean, M. 1999. 'Corporate Governance in France and the UK: Long-Term Perspectives on Contemporary Institutional Arrangements', Business History vol. 41, no. 1: 88-116.

MacLean, M. 2002 Economic Management and French Business Palgrave.

Morin, F. 1998. Le modèle francaise de détention et de gestion du capital: analyse, prospective et comparaisons internationales' Paris: Editions de Bercy

Morin, F. 2000. 'A Transformation in the French Model of Shareholding and Management', Economy and Society, vol. 29, no. 1: 36-53.

Muet, P-A., Fonteneau, A. 1985. La Gauche face à la crise Paris: FNSP

O' Sullivan, M. 2001. 'Continuity and Change in the French System of corporate

governance' INSEAD Working Paper.

O' Sullivan, M. 2003. 'The political economy of comparative corporate governance'

Review of International Political Economy 10: 1 23-72.

OECD (1999) Principes relatifs au gouvernement d'entreprise (Paris: OECD)

Perraton, J. \& Clift, B. (eds.) 2004. 'Where Are National Capitalisms Now?' Basingstoke: Palgrave.

Schmidt, V. 1996. From State to Market? The Transformation of French Business and Government. Cambridge: Cambridge University Press.

Schmidt, V. 1997. 'Running on empty: the end of dirigisme in French economic leadership', Modern and Contemporary France vol. 5, no. 2: 229-41.

Schmidt, V. 1999. 'Privatisation in France: The Transformation of French Capitalism' Environment and Planning, vol. 17, no. 4: 445-61. 
Schmidt, V. 2003. 'French capitalism transformed, yet still a third variety of capitalism' Economy and Society, vol. 32, no. 4: 526-554.

Shonfield, A. 1969. Modern Capitalism: The Changing Balance of Public and Private Power. London: Oxford University Press.

Soskice, D. 1996 'Stakeholding Yes; the German Model No’ in Kelly, Kelly \& Gamble (eds.) Stakeholder Capitalism (Basingstoke ; Macmillan)

UNCTAD 2003. World Investment Report 2003: Country Fact Sheet: France

Zysman, J. 1983. Government, Markets, Growth: Financial Systems and the Politics of Industrial Change. Ithaca: Cornell University Press. 